\title{
Response of Chickpea to application of Humic Acid along with Vermicompost on Uptake of Nutrients, Yield attributes and Yield
}

\author{
Shreelatha ${ }^{1}$, S. N. Bhat ${ }^{1 *}$, S. R. Balanagoudar ${ }^{1}$, Anand S Kmble ${ }^{2}$, \\ Satyanarayana Rao $^{2}$ and R. V. Beladhadi ${ }^{1}$ \\ ${ }^{1}$ Department of Soil Science and Agril. Chemistry, ${ }^{2}$ Department of Agronomy \\ University of Agricultural Sciences, Raichur- 584 104(Karnataka), India \\ *Corresponding author
}

\begin{tabular}{|c|}
\hline Keywords \\
\hline $\begin{array}{l}\text { Humic acid, } \\
\text { Chickpea, Nutrient } \\
\text { uptake and Yield }\end{array}$ \\
\hline Article Info \\
\hline $\begin{array}{l}\text { Accepted: } \\
\text { 22 December } 2019 \\
\text { Available Online: } \\
20 \text { January } 2020\end{array}$ \\
\hline
\end{tabular}

\section{A B S T R A C T}

Field experiment pertaining to response of chickpea to application of Humic Acid (HA) along with vermicompost was carried out at Organic Farming Research Institute, UAS, Raichur during 2018-19. The HA was extracted from pressmud and tested on chickpea crop through soil application and foliar spray. This field experiment was laid out in RCBD with 11 treatments comprising of 75 per cent and 100 per cent recommended dose of $\mathrm{N}$ and $\mathrm{P}$ through vermicompost ( $\mathrm{VC}$ ) and rock phosphate (RP) along with soil application and foliar spray of humic acid. The treatments were replicated thrice. Higher seed and stover yield of chickpea (1659 \& $1743.7 \mathrm{~kg} \mathrm{ha}^{-1}$ ), pods per plant (77.0), 100 seed weight $(24.3 \mathrm{~g})$ and better uptake of major and micronutrients by seed and straw of chickpea was recorded due to application of recommended dose of $\mathrm{N}$ and $\mathrm{P}$ through VC and RP along with soil application of HA @ $5 \mathrm{~kg} \mathrm{ha}^{-1}$ and foliar spray@0.25 per cent compared to other treatments.

\section{Introduction}

Organic matter is considered as the "Life of soil" due to its importance in maintaining fertility of the soil, it become a major threat to food security in the years to come. Organic sources provide substantial quantity of nutrient elements as well as humus which helps in improving soil physical, chemical and biological properties of soil. However, to improve the organic matter content of soils many management techniques have been adopted such as crop rotation, plough techniques, green manuring and application of animal residues, application of humic acids and humates.

Use of bulky organic manures has been considered as a burden by the farmers as it requires large number of labourers for 
transportation and application. Also, use of bulky organic manures results in spreading of weed seeds in crop land and control of weeds would also be a major problem. In this context, extraction of humic substances from bulky organic manures and their use may help solve many problems associated with use of bulky organic manures. This extracted humic acid can be used as an amendment to improve the physical, chemical and biological properties of soil. Humic substances influence many soil properties irrespective of the quantities present.

Chickpea (Cicer arietinum L.) is one of the important legume crop and rich in protein content. Its seeds are used as a vegetable and dry bean. In fact, it is a multipurpose crop used in human diets, animal fodder and industrial purposes. It is the most important pulse crop cultivated during Rabi season mainly in semi-arid regions.

In India, it is cultivated over an area of 9.93 million hectares with an annual production of 9.53 million tonnes and with a productivity of $960 \mathrm{~kg} \mathrm{ha}^{-1}$ (Anon., 2015). The area under chickpea in Karnataka is 0.92 million hectares with 0.57 million tonnes of production and with $622 \mathrm{~kg} \mathrm{ha}{ }^{-1}$ of productivity. In Karnataka, Kalaburagi district occupies the first position in chickpea area (0.16 million hectares) with a production of 0.11 million tonnes and productivity $\left(0.74 \mathrm{t} \mathrm{ha}^{-1}\right)$ followed by Vijayapura and Bagalakot districts (Anon., 2015). Keeping these points in view, the present investigation to know the response of chickpea to application of humic acid derived from pressmud was initiated in black soil.

\section{Materials and Methods}

The field experiment was conducted at Organic farming Research Institute, U.A.S., Raichur during rabi, 2018-19. The experiment was laid out in RCBD with three replications.
The experiment comprised of 11 treatments, viz; Treatment $\mathrm{T}_{1}$ to $\mathrm{T}_{4}$ received $75 \% \mathrm{RDN}$ and RDP through VC and RP along with soil application of HA @ $5 \mathrm{~kg} / \mathrm{ha}$ and foliar spray @ $0.25 \%$ or $0.5 \%$; treatment $\mathrm{T}_{5}$ to $\mathrm{T}_{8}$ received $100 \%$ RDN and RDP through VC and RP along with soil application of HA @ 5 $\mathrm{kg} / \mathrm{ha}$ and foliar spray @ $0.25 \%$ or $0.5 \% ; \mathrm{T}_{9}$ to $\mathrm{T}_{10}: 100 \% \mathrm{~N}$ and $\mathrm{P}$ through $\mathrm{VC}$ and $\mathrm{RP}$ along with foliar spray of HA @ $0.25 \%$ or $0.5 \% ; \mathrm{T}_{11}: \operatorname{RDF}($ 10:25:0 $\mathrm{kg} / \mathrm{ha})$. The properties of HA derived from PM and VC are furnished in Table 1.

The composite surface soil sample was collected from the experimental site and analysed for initial soil fertility. The soil was clayey in texture, slightly alkaline in reaction $(\mathrm{pH} 7.70)$, low in soluble salts (EC; 0.70 $\left.\mathrm{dSm}^{-1}\right)$ and medium in organic carbon content ( 0.67 per cent), low in available nitrogen (132.5 kg ha $\left.\mathrm{kg}^{-1}\right)$, high in available phosphorous $\left(58.4 \mathrm{~kg} \mathrm{ha}^{-1}\right)$, potassium (670.0 kg ha $\left.{ }^{-1}\right)$ and sulphur (55.0 kg ha ${ }^{-1}$ ). Chickpea crop (variety JG-11) was grown during Rabi season under rainfed condition following organic package developed by UAS, Raichur.

\section{Results and Discussion}

\section{Yield and yield attributing parameters of chickpea}

The effect of humic acid application on yield and yield attributing parameters of chickpea crop viz., number of pods per plant, 100 seed weight $(\mathrm{g})$, seed yield $\left(\mathrm{kg} \mathrm{ha}^{-1}\right)$, and stover yield $\left(\mathrm{kg} \mathrm{ha}^{-1}\right)$ were found to be significant( Table 2).

\section{Number of pods per plant}

Among the treatments, the significantly higher number of pods per plant (77.0) was recorded in $\mathrm{T}_{7}$ treatment due to application of recommended dose of $\mathrm{N}$ and $\mathrm{P}$ through $\mathrm{VC}$ 
and RP along with soil application of humic acid@5 kg ha-1 and foliar spray of humic acid@0.25 per cent and was at par with $\mathrm{T}_{8}$ treatment (76.0) which received same quantity of nutrients except foliar application of humic acid @0.5 per cent.

Number of pods per plant recorded were statistically equal in the treatment $\mathrm{T}_{2}(54.3)$ with $\mathrm{T}_{1}(56.3), \mathrm{T}_{3}(59.7)$ with $\mathrm{T}_{4}(61.0)$ and $\mathrm{T}_{5}$ (59.0). The lower number of pods per plant recorded in the treatment receiving 75 per cent substitution of both $\mathrm{N}$ and $\mathrm{P}$ compared to the treatment receiving full dose of recommended $\mathrm{N}$ and $\mathrm{P}$ along with $\mathrm{HA}$ application might be due to lesser availability of nutrients resulted from vermicompost. On the other hand, relatively higher number of pods per plant was registered with application of 100 percent $\mathrm{N}$ and $\mathrm{P}$ through $\mathrm{VC}$ and $\mathrm{RP}$ along with humic acid soil application and/ or foliar spray. Similar findings were reported by Talavia et al., (2007) in groundnut who observed highest pod yield (1286 $\left.\mathrm{kg} \mathrm{ha}^{-1}\right)$ and haulm yield (2746 kg ha-1) of groundnut with combined application of RDF + humic acid @ $20 \mathrm{~kg} \mathrm{ha}^{-1}$.

\section{Test weight (100 seed weight)}

There was a significant difference in test weight of chickpea seeds among the treatments. Treatment $\mathrm{T}_{7}: 100$ per cent $\mathrm{RDN}$ and RDP through VC and RP and soil application of humic acid along with foliar spray of humic acid @ 0.25 per cent recorded significantly higher seed weight $(24.3 \mathrm{~g})$ which was at par with treatment $\mathrm{T}_{8}: 100$ per cent RDN and RDP through VC and RP along with soil application of humic acid @ 5 $\mathrm{kg} \mathrm{ha}{ }^{-1}+$ foliar spray @ 0.5 per cent $(23.7 \mathrm{~g})$. The previous two treatments $\left(\mathrm{T}_{7} \& \mathrm{~T}_{8}\right)$ have significantly higher seed weight than that of $\mathrm{T}_{11} \quad$ treatment $(21.2 \mathrm{~g})$ receiving recommended dose of inorganic fertilizers. The seed weight recorded with $\mathrm{T}_{2}$ treatment
(20.3 g) was at par with $\mathrm{T}_{3}(20.8 \mathrm{~g})$ and $\mathrm{T}_{1}$ (19.7 g).

\section{Seed and straw yield}

The data on seed yield and straw yield of chickpea differed significantly among the treatments (Table $1 \&$ fig. 1)). The treatment receiving 100 per cent substitution of recommended $\mathrm{N}$ and $\mathrm{P}$ through $\mathrm{VC}$ and $\mathrm{RP}$ along with application of humic acid to soil and/or foliar spray recorded relatively higher seed yield compared to that receiving only 75 per cent substitution of recommended $\mathrm{N}$ and $\mathrm{P}$ through VC and RP.

Among the different treatments, the treatment receiving 100 per cent $\mathrm{N}$ and $\mathrm{P}$ substitution through VC and RP along with soil application of humic acid @ $5 \mathrm{~kg} \mathrm{ha}^{-1}$ along with foliar spray @ 0.25 per cent recorded significantly higher grain yield $\left(\mathrm{T}_{7}: 1659 \mathrm{~kg}\right.$ $\mathrm{ha}^{-1}$ ) compared to rest of the treatments. However, the seed yield obtained in the latter treatment $\left(\mathrm{T}_{7}\right)$ was at par with that recorded in $\mathrm{T}_{8}$ treatment $\left(1579.60 \mathrm{~kg} \mathrm{ha}^{-1}\right)$ with the same quantity of $\mathrm{N}$ and $\mathrm{P}$ as well as soil application of humic acid but variation in the concentration of HA used for foliar spray $(0.5$ $\%)$ (Plate. 7 and 8). From these results it appears that soil application of humic acid @ $5 \mathrm{~kg} \mathrm{ha}^{-1}+$ foliar spray @ 0.25 per cent along with recommended dose of $\mathrm{N}$ and $\mathrm{P}$ is sufficient to attain higher yield of chickpea. Further, among treatments having 100 per cent supplement of both $\mathrm{N}$ and $\mathrm{P}$, on par seed yield was recorded with $\mathrm{T}_{7}\left(1659.0 \mathrm{~kg} \mathrm{ha}^{-1}\right)$, $\mathrm{T}_{8}\left(1579.6 \mathrm{~kg} \mathrm{ha}^{-1}\right)$ and $\mathrm{T}_{6}$ treatment $(1565.1$ $\left.\mathrm{kg} \mathrm{ha}^{-1}\right)$. Application of RDF recorded lower seed yield (1412.6 $\mathrm{kg} \mathrm{ha}^{-1}$ ) in comparison with above said treatments (plate 1). Relatively higher seed yield recorded with recommended dose of $\mathrm{N}$ and $\mathrm{P}$ through $\mathrm{VC}$ and RP along with soil application of humic acid + foliar spray @ 0.25 per cent or 0.5 per cent is attributed to improvement in physical 
condition of soil, improved growth and yield attributing characters in chickpea crop, higher translocation of nutrients from source to sink as well as more uptake of nutrients by the plant. The present investigation was in line with the findings of Veeral et al., (2003) in rice-black gram and Talavia et al., (2007) in groundnut.

Similarly, the treatment receiving 100 per cent substitution of recommended $\mathrm{N}$ and $\mathrm{P}$ through VC and RP along with application of humic acid to soil and/or foliar spray recorded relatively higher straw yield compared to that receiving only 75 per cent substitution of recommended $\mathrm{N}$ and $\mathrm{P}$ through $\mathrm{VC}$ and $\mathrm{RP}$.

The straw yield (1743.7 $\left.\mathrm{kg} \quad \mathrm{ha}^{-1}\right)$ was significantly higher with $\mathrm{T}_{7}$ treatment receiving 100 per cent recommended dose of $\mathrm{N}$ and $\mathrm{P}$ through $\mathrm{VC}$ and $\mathrm{RP}$ along with soil application of humic acid @ $5 \mathrm{~kg} \mathrm{ha}^{-1}$ and foliar spray@0.25 per cent and was at par with T8 treatment that receiving 100 per cent recommended dose of $\mathrm{N}$ and $\mathrm{P}$ through $\mathrm{VC}$ and RP along with soil application of humic acid@ $5 \mathrm{~kg} \mathrm{ha}^{-1}$ along with foliar spray @ 0.5 per cent $\left(1719.0 \mathrm{~kg} \mathrm{ha}^{-1}\right)$. And application of RDF recorded lower straw yield $(1586.3 \mathrm{~kg}$ $\mathrm{ha}^{-1}$ ) in comparison with above said treatments.

Increased yield and yield parameters due to combined use of organic materials + humic acid as soil and foliar application was due to higher availability of plant nutrients and balanced supply of nutrients, efficient translocation of photosynthates and availability of adequate amount of nutrients (Thakur et al., 2013). They have reported 8 to 20 per cent increase in wheat yield, 14 per cent in rice yield, 8 per cent in vegetables and 44 per cent in radish yield with application of HA. Nandakumar (2004) observed higher grain yield of rice with humic acid @ $20 \mathrm{~kg}$ $\mathrm{ha}^{-1}$ along with 100 per cent NPK and the per cent increase in grain yield over control was 50.41 and 53.84 per cent in clay loam and sandy loam soils, respectively. Balasubramaniam et al., (2000) reported that the yield attributes viz., grain and stover yield of soybean increased significantly with addition of humic acid @ $20 \mathrm{~kg} \mathrm{ha}^{-1}$ to soil along with spraying $(0.01 \%)$ at flowering stage. Khungar and Manoharan (2000) reported that the humic acid application @ 10 $\mathrm{kg} \mathrm{ha}^{-1}$ to green gram and soybean resulted in yield increase by 80.65 and 71.07 per cent, respectively.

\section{Effect of different treatments on nutrient uptake by chickpea seed and straw}

The uptake of $\mathrm{N}, \mathrm{P}$ and $\mathrm{K}$ by grain and straw was found to be relatively lower with 75 per cent recommended dose of $\mathrm{N}$ and $\mathrm{P}$ through $\mathrm{VC}$ and RP compared to 100 per cent supplementation of $\mathrm{N}$ and $\mathrm{P}$ along with or without HA application (Table 3)

\section{Nitrogen uptake by seed and straw}

Uptake of nitrogen in seed and straw differed significantly among the treatments recording significantly higher $\mathrm{N}$ uptake by seed $\left(\mathrm{T}_{7}\right.$ : $69.21 \mathrm{~kg} \mathrm{ha}^{-1}$ ) due to soil application of humic acid@ $5 \mathrm{~kg}^{-1}$ ha along with recommended dose of $\mathrm{N}$ and $\mathrm{P}$ applied to the crop through VC and RP followed by foliar spray of HA @ 0.25 per cent twice during 45 and 60 DAS. The $\mathrm{N}$ uptake of seed in $\mathrm{T}_{7}$ treatment was at par with treatment $\mathrm{T}_{8}\left(68.17 \mathrm{~kg} \mathrm{ha}^{-1}: 100\right.$ per cent $\mathrm{N}$ and $\mathrm{P}$ through $\mathrm{VC}$ and $\mathrm{RP}+$ soli application of HA @ $5 \mathrm{~kg} \mathrm{ha}^{-1}+$ foliar spray @ $0.5 \%)$ and T6 treatment $\left(62.30 \mathrm{~kg} \mathrm{ha}^{-1}\right.$ : 100 per cent $\mathrm{N}$ and $\mathrm{P}$ through $\mathrm{VC}$ and $\mathrm{RP}+$ soil application of HA @ $5 \mathrm{~kg} \mathrm{ha}^{-1}$ ). Similar trend of result in uptake of nitrogen by straw was noticed, recording significantly higher uptake of $\mathrm{N}\left(29.30 \mathrm{~kg} \mathrm{ha}^{-1}\right)$ with $\mathrm{T}_{7}$ treatment was (100 per cent $\mathrm{N}$ and $\mathrm{P}$ through $\mathrm{VC}$ and $\mathrm{RP}+$ soil application of HA @ $5 \mathrm{~kg} \mathrm{ha}^{-1}$ and 
foliar spray of humic acid @ $0.25 \%$ ) which was at par with other treatments except $\mathrm{T}_{8}$ receiving recommended dosed of $\mathrm{N}$ and $\mathrm{P}$ through VC and RP along with soil application HA @ $5 \mathrm{~kg} \mathrm{ha}^{-1}$ and foliar spray @ 0.5 per cent(24.39 $\left.\mathrm{kg} \mathrm{ha}^{-1}\right)$. Significantly lower uptake of $\mathrm{N}$ by the seed was recorded with application of RDF (53.45 $\left.\mathrm{kg} \mathrm{ha}^{-1}\right)$.

The higher $\mathrm{N}$ uptake occurred in $\mathrm{T}_{7}$ treatment was because of the fact that the humic substances work on the metabolism of the plant and the effect is mainly exerted on the cell membrane functions and thus promoting nutrient uptake or plant growth and acting as a hormone-like substance. Besides, higher nitrogen uptake by crop might also be due to better physical condition of soil facilitated with vermicompost application.

\section{Phosphorus uptake by seed and straw}

Uptake of phosphorus (P) by seed and straw differed significantly among the treatments. The significantly higher uptake of $\mathrm{P}$ by seed (3.16 kg ha ${ }^{-1}$ ) and straw (2.61 kg ha ${ }^{-1}$ ) was recorded with soil application of humic acid @ $5 \mathrm{~kg} \mathrm{ha}^{-1}$ and recommended dose of $\mathrm{N}$ and $\mathrm{P}$ through VC and RP followed by foliar spray of humic acid @ 0.25 per cent $\left(\mathrm{T}_{7}\right)$ and was on par with $\mathrm{T}_{8}$ treatment where humic acid was applied to soil @ $5 \mathrm{~kg} \mathrm{ha}^{-1}$ along with 100 per cent $\mathrm{N}$ and $\mathrm{P}$ through $\mathrm{VC}$ and RP and foliar spray of HA @ 0.5 per cent. Among 100 per cent $\mathrm{N}$ and $\mathrm{P}$ substitution treatments, the lower P uptake by the seed and straw, respectively was recorded with RDF treatment $(2.34 \& 1.98 \%)$.

The enhanced $\mathrm{P}$ uptake in $\mathrm{T}_{7}$ and $\mathrm{T}_{8}$ may be due to the conversion of insoluble form of $\mathrm{P}$ to soluble form resulting in higher $P$ availability. The HA increases $P$ availability and uptake by decreasing calcium phosphate (Ca-P) precipitation rates, competing for adsorption sites and decreasing the number of adsorption sites by promoting dissolution of metals present on solid phases by chelation (Inskeep and Silvertooth, 1988; Sibanda and Young, 1986 and Guppy et al., 2005).

Table.1 Properties of humic acid derived from pressmud and vermicompost

\begin{tabular}{|l|c|c|}
\hline Parameter & Pressmud & Vermicompost \\
\hline Humic acid yield (\%) & 13.58 & 10.58 \\
\hline Ash content (\%) & 1.0 & 3.0 \\
\hline pH & 4.18 & 4.08 \\
\hline Total organic carbon & 57.4 & 56.2 \\
\hline Humic acid content $(\boldsymbol{\%})$ & 12.0 & 5.4 \\
\hline Total nitrogen $(\mathbf{\%})$ & 1.75 & 1.02 \\
\hline Total phosphorus(\%) & 0.061 & 0.040 \\
\hline Total potassium(\%) & 0.15 & 0.11 \\
\hline Total Fe(mg/kg) & 5992.5 & 3345.0 \\
\hline Total Mn(mg/kg) & 802.8 & 515.3 \\
\hline Total Cu(mg/kg) & 145.5 & 118.5 \\
\hline Total Zn(mg/kg) & 280.6 & 263.0 \\
\hline
\end{tabular}


Table.2 Yield attributes and yield of chickpea as influenced by different treatments

\begin{tabular}{|c|c|c|c|c|}
\hline Treatments & $\begin{array}{c}\text { Number of } \\
\text { pods } \\
\text { plant }^{-1}\end{array}$ & $\begin{array}{c}100 \text { seed } \\
\text { weight }(g)\end{array}$ & $\begin{array}{c}\text { Seed } \\
\text { yield } \\
\left(\mathrm{kg} \mathrm{ha}^{-1}\right)\end{array}$ & $\begin{array}{c}\text { Straw } \\
\text { yield } \\
\left(\mathrm{kg} \mathrm{ha}^{-1}\right)\end{array}$ \\
\hline$T_{1:} 75 \%$ RDN \& RDP through VC \& RP + SA of HA @ $5 \mathrm{~kg} \mathrm{ha}^{-1}$ & 56.3 & 19.7 & 1132.7 & 1213.7 \\
\hline$T_{2}: 75 \%$ RDN \& RDP through VC \& RP + FS of HA @0.5 \% & 54.3 & 20.3 & 1247.5 & 1335.3 \\
\hline $\begin{array}{l}T_{3}: 75 \% \text { RDN \& RDP through VC \& RP + SA of HA@5 kg ha }{ }^{-1}+\text { FS } \\
\text { of HA@0.25\% }\end{array}$ & 59.7 & 20.8 & 1332.7 & 1356.3 \\
\hline $\begin{array}{l}T_{4}: 75 \% \text { RDN \& RDP through VC \& RP + SA of HA@ } 5 \mathrm{~kg} \mathrm{ha}^{-1}+\mathrm{FS} \\
\text { of HA@0.5\% }\end{array}$ & 61.0 & 21.6 & 1288.6 & 1460.0 \\
\hline$T_{5}: 100 \%$ RDN \& RDP through VC \&RP & 59.0 & 21.9 & 1438.0 & 1632.3 \\
\hline$T_{6}: 100 \%$ RDN \&RDP through VC \& RP +SA of HA@ $5 \mathrm{~kg} \mathrm{ha}^{-1}$ & 64.0 & 22.0 & 1565.1 & 1644.7 \\
\hline $\begin{array}{l}\text { T }_{7}: 100 \% \text { RDN \&RDP through VC \& RP +SA of HA @ } 5 \mathrm{~kg} \mathrm{ha}^{-1}+\mathrm{FS} \\
\text { of HA @0.25\% }\end{array}$ & 77.0 & 24.3 & 1659.0 & 1743.7 \\
\hline $\begin{array}{l}\text { T8: 100\% RDN \&RDP through VC \& RP +SA of HA @ } 5 \mathrm{~kg} \mathrm{ha}^{-1}+\mathrm{FS} \\
\text { of HA @0.5\% }\end{array}$ & 76.0 & 23.7 & 1579.6 & 1719.0 \\
\hline$T_{9}: 100 \%$ RDN \& RDP through VC \&RP +FS of HA @0.25\% & 63. & 20.3 & 1426.9 & 1449.0 \\
\hline$T_{10}: 100 \%$ RDN \& RDP through VC \&RP+ FS of HA@0.5 \% & 64.0 & 20.7 & 1454.9 & 1422.0 \\
\hline$T_{11}: \operatorname{RDF}\left(10: 25: 0 \mathrm{~kg} \mathrm{ha}^{-1}\right)$ & 67.0 & 21.2 & 1412.6 & 1586.3 \\
\hline S. Em. \pm & 1.16 & 0.33 & 8.79 & 75.09 \\
\hline C.D at $5 \%$ & 3.41 & 0.98 & 25.94 & 221.53 \\
\hline
\end{tabular}

Note: RDN: Recommended dose of nitrogen, RDP: Recommended dose of phosphorus, RP: Rock phosphate, VC: vermicompost

RDF: Recommended dose of fertilizers, HA: Humic Acid, SA : Soil Application, FS: Foliar spray 
Table.3 Major nutrient uptake by seed and straw after harvest of the chickpea as influenced by the different treatments

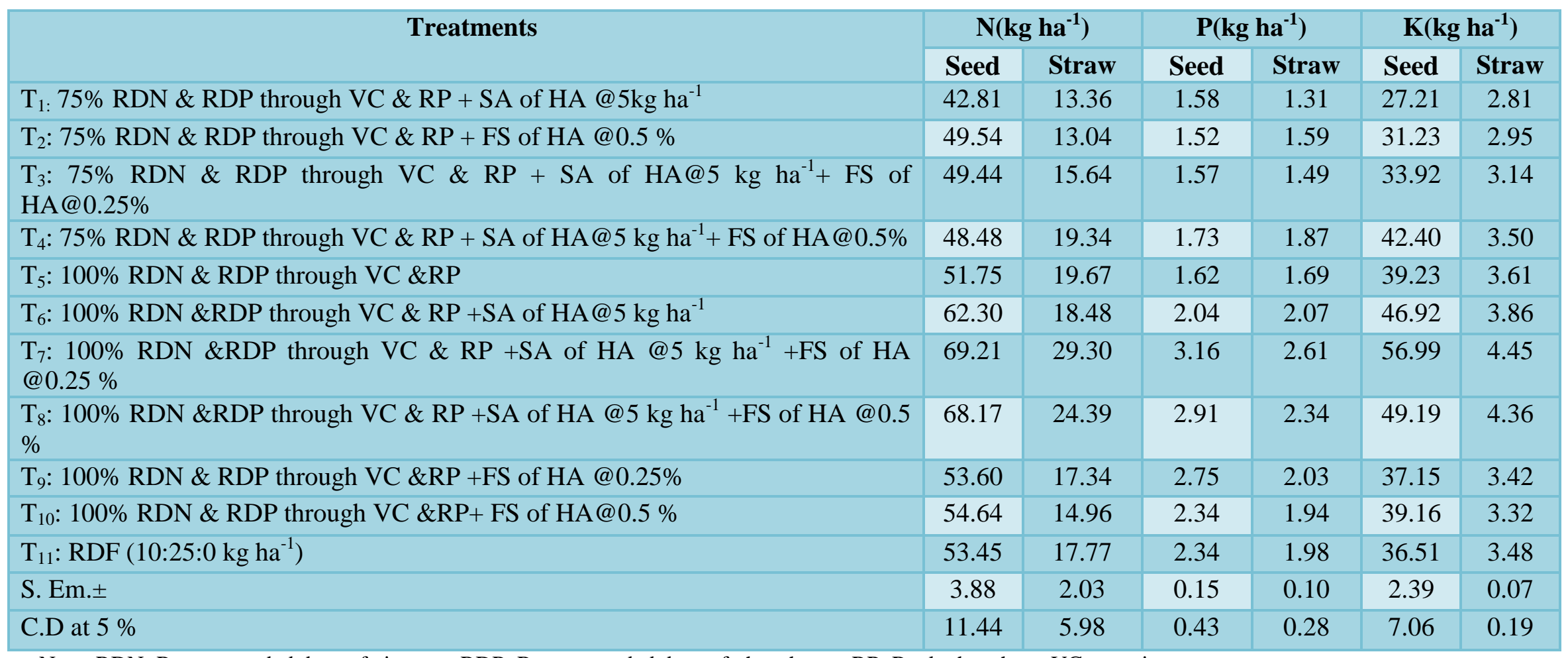

Note: RDN: Recommended dose of nitrogen, RDP: Recommended dose of phosphorus, RP: Rock phosphate, VC: vermicompost RDF: Recommended dose of fertilizers, HA : Humic Acid, SA : Soil Application, FS: Foliar spray, NS: Non significant. 
Table.4 Micro nutrient uptake by seed and straw after harvest of chickpea as influenced by the different treatments

\begin{tabular}{|c|c|c|c|c|c|c|c|c|}
\hline \multirow[t]{2}{*}{ Treatments } & \multicolumn{2}{|c|}{$\mathrm{Cu}\left(\mathrm{g} \mathrm{ha}^{-1}\right)$} & \multicolumn{2}{|c|}{$\mathrm{Fe}\left(\mathrm{g} \mathrm{ha}^{-1}\right)$} & \multicolumn{2}{|c|}{$\operatorname{Mn}\left(\mathrm{g} \mathrm{ha}^{-1}\right)$} & \multicolumn{2}{|c|}{$\mathrm{Zn}\left(\mathrm{g} \mathrm{ha}^{-1}\right)$} \\
\hline & Seed & Straw & Seed & Straw & Seed & Straw & Seed & Straw \\
\hline $\mathrm{T}_{1:} 75 \% \mathrm{RDN} \& \mathrm{RDP}$ through VC \& RP + SA of HA @ $5 \mathrm{~kg} \mathrm{ha}^{-1}$ & 12.74 & 17.60 & 163.93 & 324.0 & 49.58 & 91.9 & 47.95 & 39.2 \\
\hline $\mathrm{T}_{2}: 75 \%$ RDN \& RDP through VC \& RP + FS of HA @ $0.5 \%$ & 13.63 & 22.71 & 189.05 & 438.5 & 56.01 & 121.7 & 54.84 & 47.3 \\
\hline $\begin{array}{l}\mathrm{T}_{3}: 75 \% \text { RDN \& RDP through VC \& RP + SA of HA@ } 9 \mathrm{~kg} \mathrm{ha}^{-} \\
\text {+ FS of HA@ @ } 0.25 \%\end{array}$ & 14.14 & 19.75 & 208.45 & 382.7 & 59.36 & 111.7 & 59.52 & 44.0 \\
\hline $\begin{array}{l}\mathrm{T}_{4}: 75 \% \text { RDN \& RDP through VC \& RP + SA of HA@ } 9 \mathrm{~kg} \mathrm{ha}^{-} \\
{ }^{+} \mathrm{FS} \text { of HA@ } 0.5 \%\end{array}$ & 16.12 & 21.36 & 216.76 & 416.0 & 66.08 & 120.4 & 64.62 & 47.8 \\
\hline $\mathrm{T}_{5}: 100 \% \mathrm{RDN} \& \mathrm{RDP}$ through VC \&RP & 13.61 & 23.65 & 187.32 & 469.7 & 55.97 & 107.4 & 56.59 & 49.0 \\
\hline $\mathrm{T}_{6}: 100 \% \mathrm{RDN} \& \mathrm{RDP}$ through VC \& RP +SA of HA@ $5 \mathrm{~kg} \mathrm{ha}^{-1}$ & 17.94 & 24.99 & 250.70 & 474.5 & 70.66 & 128.5 & 69.91 & 56.0 \\
\hline $\begin{array}{l}\mathrm{T}_{7}: 100 \% \mathrm{RDN} \& \mathrm{RDP} \text { through VC \& RP +SA of HA @ } 5 \mathrm{~kg} \mathrm{ha}^{-1} \\
+\mathrm{FS} \text { of HA @ } 0.25 \%\end{array}$ & 19.30 & 28.47 & 310.42 & 550.1 & 77.07 & 130.8 & 85.41 & 63.3 \\
\hline $\begin{array}{l}\mathrm{T}_{8}: 100 \% \mathrm{RDN} \& \mathrm{RDP} \text { through VC \& RP +SA of HA @ } 5 \mathrm{~kg} \mathrm{ha}^{-1} \\
+\mathrm{FS} \text { of HA @ } 0.5 \%\end{array}$ & 17.98 & 26.17 & 277.42 & 531.5 & 76.97 & 129.2 & 75.86 & 61.6 \\
\hline $\mathrm{T}_{9}: 100 \%$ RDN \& RDP through VC \&RP +FS of HA @ $0.25 \%$ & 15.54 & 19.67 & 233.70 & 424.8 & 64.63 & 107.8 & 64.70 & 50.0 \\
\hline $\mathrm{T}_{10}: 100 \%$ RDN \& RDP through VC \&RP+FS of HA@ $0.5 \%$ & 15.16 & 24.64 & 235.37 & 494.8 & 66.71 & 123.4 & 65.68 & 58.4 \\
\hline $\mathrm{T}_{11}: \operatorname{RDF}\left(10: 25: 0 \mathrm{~kg} \mathrm{ha}^{-1}\right)$ & 9.40 & 24.97 & 200.14 & 418.0 & 62.89 & 107.5 & 60.47 & 47.8 \\
\hline S. Em. \pm & 1.87 & 1.30 & 14.73 & 33.108 & 4.86 & 12.025 & 4.35 & 3.667 \\
\hline C.D at $5 \%$ & NS & 3.84 & 43.47 & 82.988 & 14.34 & NS & 12.85 & 10.818 \\
\hline
\end{tabular}

Note: RDN: Recommended dose of nitrogen, RDP: Recommended dose of phosphorus, RP: Rock phosphate, VC: vermicompost

RDF: Recommended dose of fertilizers, HA : Humic Acid, SA : Soil Application, FS: Foliar spray, NS: Non significant 
Fig.1 Seed and stover yield of chickpea as influenced by different treatments

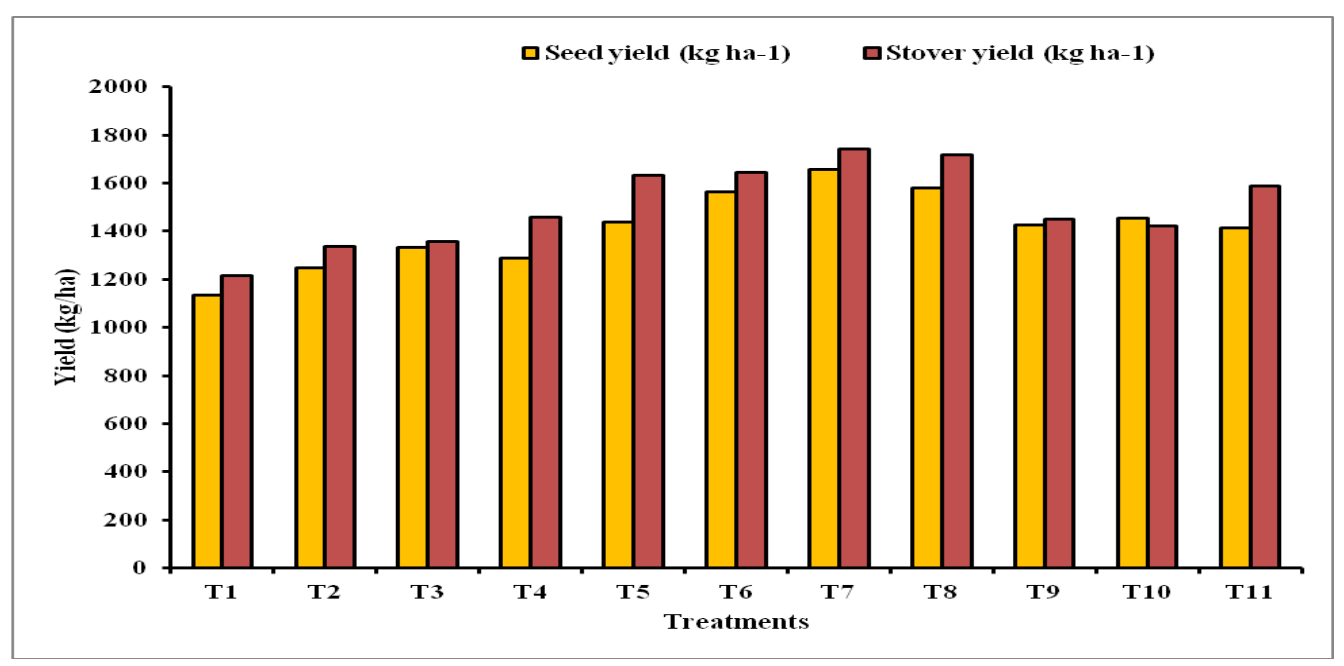

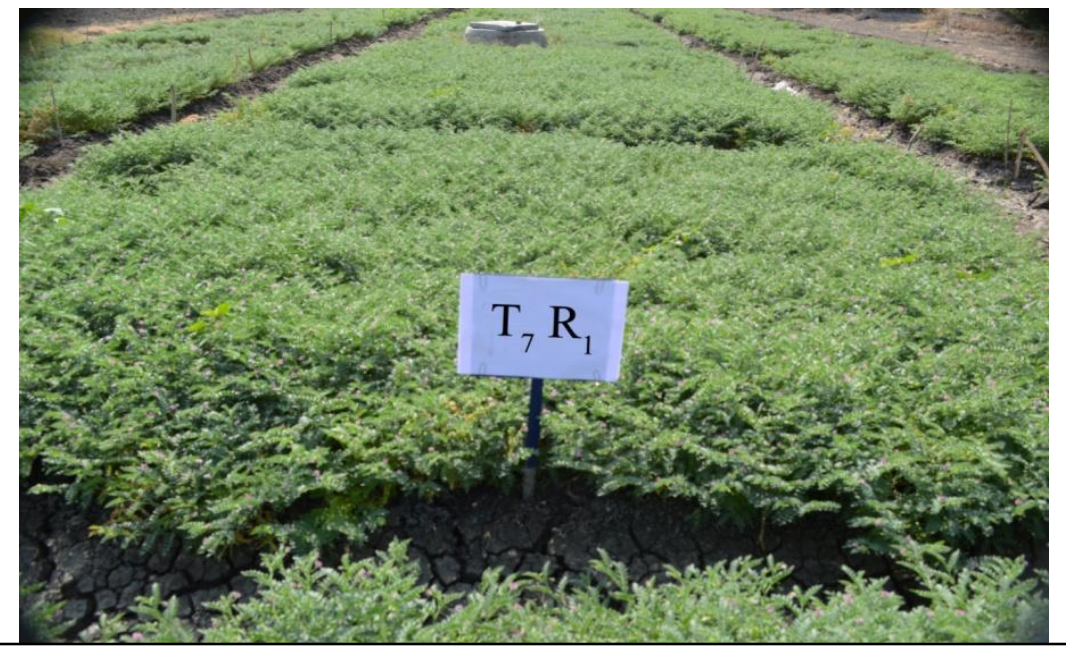

Plate 1. $100 \%$ RDN and RDP through VC \& RP and soil application of HA @ $5 \mathrm{~kg} \mathrm{ha}^{-1}+$ FS @ $0.25 \%$

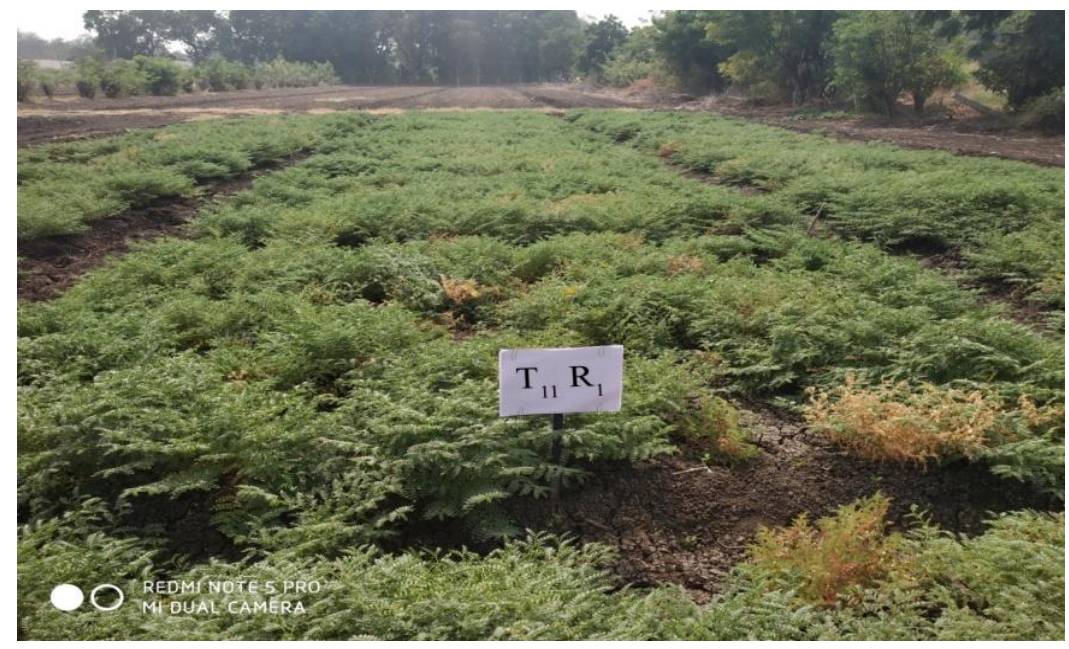

Plate 2. RDF (10:25:0 NPK kg ha' $\left.{ }^{-1}\right)$ 


\section{Potassium uptake by seed and straw}

The potassium uptake in seed and straw of chickpea differed significantly among the treatments and the significantly higher $\mathrm{K}$ uptake by the seed $\left(56.99 \mathrm{~kg} \mathrm{ha}^{-1}\right)$ was recorded with soil application of humic acid @ $5 \mathrm{~kg} \mathrm{ha}^{-1}$ along with recommended dose of $\mathrm{N}$ and $\mathrm{P}$ supplied through VC and RP and foliar spray of humic acid @ 0.25 per cent $\left(\mathrm{T}_{7}\right)$ and was significantly superior over rest of the treatments. The lower $\mathrm{K}$ uptake recorded with RDF ( $\left.\mathrm{T}_{11}: 36.51 \mathrm{~kg} \mathrm{ha}^{-1}\right)$ was at par with $\mathrm{T}_{9}$ $\left(37.15 \mathrm{~kg} \mathrm{ha}^{-1}\right)$ and $\mathrm{T}_{10}\left(39.16 \mathrm{~kg} \mathrm{ha}^{-1}\right)$.

As found in seed, $\mathrm{K}$ uptake by the straw was also significantly higher with full dose of $\mathrm{N}$ and $\mathrm{P}$ application through $\mathrm{VC}$ and $\mathrm{RP}$ along with soil application of HA @ $5 \mathrm{~kg} \mathrm{ha}^{-1}$ and foliar spray@0.25 per cent $\left(\mathrm{T}_{7}\right)$. The $\mathrm{k}$ uptake recorded by the straw under $\mathrm{T}_{7}(4.45$ $\left.\mathrm{kg} \mathrm{ha}^{-1}\right)$ and $\mathrm{T}_{8}$ treatment $\left(4.6 \mathrm{~kg} \mathrm{ha}^{-1}\right)$ was at par with each other.

Humic acid plays a definite role in liberating fixed $\mathrm{K}$ because of their chelating activity. Similarly, increase in $\mathrm{K}$ content and uptake recorded in $T_{7}$ and $T_{8}$ treatment may be due to the reduced $\mathrm{K}$ fixation increased the permeability of bio- membranes for electrolytes with the addition of $\mathrm{HA}$ and thereby accounted for increased K uptake.

Enhanced uptake of macronutrients (N, P and $\mathrm{K})$ was due to the stimulatory effect of humic substances. Many researchers reported that soil or foliar application of HA significantly increased the macro $(\mathrm{N}, \mathrm{P}, \mathrm{K}, \mathrm{Ca}$ and $\mathrm{Mg})$ and micro nutrient $(\mathrm{Fe}, \mathrm{Cu}, \mathrm{Zn}$ and $\mathrm{Mn}$ ) contents of different crops ( Haghighi et al., 2014); in wheat (Taha et al., 2006).

Uptake of $\mathrm{Zn}, \mathrm{Cu}$, Fe and $\mathrm{Mn}$ in seed and straw

Significantly higher uptake of $\mathrm{Zn}, \mathrm{Cu}, \mathrm{Fe}$ and $\mathrm{Mn}$ ( Table 4) respectively, in seed was recorded with application of recommended dose of $\mathrm{N}$ and $\mathrm{P}$ through vermicompost and RP along with soil application of HA @ $5 \mathrm{~kg}$ $\mathrm{ha}^{-1}$ along with foliar spray of HA @ 0.25 per cent $\left(\mathrm{T}_{7}: 85.41 \mathrm{Zn}, 19.30 \mathrm{Cu}, 310.42 \mathrm{Fe} \&\right.$ $\left.77.07 \mathrm{~g} \mathrm{ha}^{-1} \mathrm{Mn}\right)$ ) and was on par with that recorded with application of recommended dose of $\mathrm{N}$ and $\mathrm{P}$ through $\mathrm{VC}$ and $\mathrm{RP}$ along with soil application of HA @ $5 \mathrm{~kg} \mathrm{ha}^{-1}$ and foliar spray of HA @ 0.5 per cent $\left(\mathrm{T}_{8}\right)$.. As found in seed, higher $\mathrm{Zn}$ uptake by the straw was observed with $\mathrm{T}_{7}$ treatment $(63.3 \mathrm{Zn}$, $28.47 \mathrm{Cu}, 550.1 \mathrm{Fe} \& 130.8 \mathrm{~g} \mathrm{ha}^{-1} \mathrm{Mn}$ ) comprising of recommended $\mathrm{N}$ and $\mathrm{P}$ along soil application of HA @ $5 \mathrm{~kg} \mathrm{ha}^{-1}$ along with foliar spray@ 0.25 per cent. But the latter treatment was on with T8 treatment in respect of uptake micronutrient cations by seed and straw of chickpea.

Higher uptake of $\mathrm{Cu}, \mathrm{Fe} \mathrm{Mn}$ and $\mathrm{Zn}$ recorded with soil application of HA and foliar spray in combination with recommended dose of $\mathrm{N}$ and $\mathrm{P}$ through VC and RP may attributed to better root proliferation, chelation of metal ions with $\mathrm{VC}$ and $\mathrm{HA}$ and depolymerization of high molecular weight complex compounds like humic acid with root exudates and enzyme present in the soil. It corroborates the findings of Fortun and Polo (1982).

\section{References}

Anonymous, 2015, Agricultural statistics at a glance, Directorate of Economics and statistics. GOI.

Balasubramanian. T. N., Govindasamy, R. and Chandrasekaran, S, 2000, Yield attributes of soybean influenced by humic acid and rhizobium in Typicchromustert. Indian J. Agric. Chem., 33: 11-15.

Fortun, C. and Polo, A. 1982, Effects of some types of humic compounds on the growth of roots of Zea mays. Agrochemica., 26: 44-54. 
Guppy, C.N., Menzies, N.W. Moody, P.W. and Blamey, F.P.C., 2005, Competitive sorption reactions between phosphorus and organic matter in soil: A review. Aust. J. Soil Sci., 43: 189-202.

Haghighi, M., Nikbhkht, A., Xia, Y. P. and Pessarakli, M., 2014, Influence of humic acid in diluted nutrient solutions on growth, nutrient efficiency and postharvest attributes of gerbera. Commun.Soil. Sci. Pl Anal., 45: 177188.

Inskeep, W.P. and Silvertooth, J.C., 1988, Inhibition of hydroxy apatite precipitation in the presence of fulvic, humic, and tannic acids. Soil Sci. Soc. Am. J., 52: 941-946.

Khungar,S.C. and Manoharan,V., 2000, Humic acid: An innovative product rich in organic nutrient. Fert. News., 45: 2325.

Nandakumar, R., Saravanan, A., Singaram, P. and Chandrasekaran, B. S., 2004, Effect of lignite humic acid on soil nutrient availability at different growth stages of rice grown on Vertisols and Alfisols. Acta Agron. Hungarica., 52(3): 227-
235.

Sibanda, H. M. and Young, S. D., 1986, Competitive adsorption of humus acids and phosphate on goethite, gibbsite and two tropical soils. European J. soil sci.,pp 37(2):197-204.

Taha, A. A., Modaihsh, A. S. and Mahjoub, M. O., 2006, Effect of some humic acids on wheat plant grown in different soils. J. Agric. Sci., 31: 4031-4039.

Talavia, B. P., Polara, K. B., Mathukia, R. K. and Golakia, B. A. 2007, Influence of humic acid on growth, yield and quality of summer groundnut (Arachis hypogaea L.) Adv. Plant Sci., 20 (2): 659-660.

Thakur, H., Rekha, K. B., Babu, S. S. N. and Padmaja, G., 2013, Effect of humic substances on growth and yield of sunflower (Helianthus annuus L.). J. Res. ANGRAU., 41(4): 106-108.

Veeral, D. K. Kuppuswamy, G. and Thanunathan, K., 2003, Direct and residual effects of lignite fly ash and humic acid on rice-black gram cropping system. Res. Crops., 4 (2): 206-209.

\section{How to cite this article:}

Shreelatha, S. N. Bhat, S. R. Balanagoudar, Anand S. Kmble, Satyanarayana Rao and Beladhadi, R. V. 2020. Response of Chickpea to application of Humic Acid along with Vermicompost on Uptake of Nutrients, Yield attributes and Yield. Int.J.Curr.Microbiol.App.Sci. 9(01): 2306-2316. doi: https://doi.org/10.20546/ijcmas.2020.901.262 